\title{
A Rare Variant of Melanoma: Clinical, Histopathological and Prognostic Features in 5 Cases of Animal Type Melanoma
}

\section{Nadir Bir Melanom Varyantı: Hayvan Tipi Melanoma Sahip 5 Olguda Klinik, Histopatolojik ve Prognostik Özellikler}

\author{
Nilay Duman ${ }^{1}$, Gül Erkin², Özay Gököz ${ }^{3}$, Aycan Uğur Kayıkçığlu ${ }^{4}$ İsmail Çelik ${ }^{5}$ \\ ${ }^{1}$ Afyon Kocatepe Üniversitesi, Tıp Fakültesi, Dermatoloji Ana Bilim Dalı, Afyonkarahisar \\ ${ }^{2}$ Hacettepe Üniversitesi, Tıp Fakültesi, Dermatoloji Ana Bilim Dall, Ankara \\ ${ }^{3}$ Hacettepe Üniversitesi, Tip Fakültesi, Patoloji Ana Bilim Dalı, Ankara \\ ${ }^{4}$ Hacettepe Üniversitesi, Tıp Fakültesi, Plastik, Rekonstrüktif Ve Estetik Cerrahi Ana Bilim Dalı, Ankara \\ ${ }^{5}$ Hacettepe Üniversitesi, Tıp Fakültesi, Prevantif Onkoloji Ana Bilim Dalı, Ankara
}

Dergiye ulaşma tarihi:29/08/2014, Dergiye kabul tarihi:04/09/2014 Doi: 10.5505/aot.2014.19484

\section{ÖZET}

Amaç: Hayvan tipi melanom, melanomun nadir bir varyantıdır. Çalışmamızda 5 olguluk serimize ait klinik, histopatolojik ve prognostik özelliklerin sunulması amaçlanmıştır.

Yöntem: Hayvan tipi melanoma sahip 5 olgu çalışmaya dahil edildi. Klinik parametreler olarak yaş, cinsiyet, lokalizasyon, boyut, lenf nodu (sentinel/bölgesel) tutulumu, takip süresi ve satellit/intransit/uzak metastaz gelişimi ve klinik evre değerlendirildi. Histopatolojik olarak hücre tipi, Breslow kalınlığı, Clark seviyesi, mitotik indeks, ülserasyon, regresyon (parsiyel/tam), lenfohistiyositik infiltrasyon (yok/hafif/yoğun) ve lenfovasküler/ perinöral invazyon varlı̆̆ değerlendirildi.

Bulgular: Hastaların ortalama yaşı $61 \pm 17$ (39-79) ve kadın/erkek oranı 3/2 idi. Lezyonların üçü (\%60) başboyun, ikisi (\%40) akral yerleşimli idi. Ortanca boyut $2.5 \mathrm{~cm}(1.5-4 \mathrm{~cm})$ ve Breslow kalınlı̆̆ $7.5 \mathrm{~mm}(4-19 \mathrm{~mm})$ idi. Tüm lezyonların Clark seviyesi V idi. Hücre tipi, üç lezyonda (\%60) epiteloid, bir lezyonda (\%20) iğsi ve bir lezyonda (\%20) epiteloid ve iğsi karakterde idi. Üç lezyonda (\%60) ülserasyon, iki lezyonda (\%40) lenfovasküler ve bir lezyonda (\%20) perinöral invazyon mevcuttu. Üç lezyonda (\%60) lenfohistiyositik infiltrat (iki lezyonda hafif ve bir lezyonda yoğun) ve bir lezyonda (\%20) regresyon (parsiyel) izlendi. Üç lezyonda $(\% 60)$ mitotik indeks $\geq 1 \mathrm{~mm}-2$ idi. İki olguda (\%40) bölgesel lenf nodunda metastaz mevcuttu. İki olguda (\%40) uzak metastaz gelişmişti.

Sonuç: Serimizde hayvan tipi melanomlar 4-8. dekadlar arasında, hem kadın hem de erkeklerde izlendi. Başboyun veya akral bölge yerleşimli idi. Son yayınlarda hayvan tipi melanomda lenf nodu tutulumunun yüksek ve uzak metastaz gelişiminin klasik melanoma kıyasla daha düşük olduğundan bahsedilmektedir. Bizim serimizde de lenf nodu tutulumu yüksekti, fakat bundan farklı olarak uzak metastaz oranı da yüksekti. Sonuç olarak bu nadir melanom varyantının gerçek biyolojik potansiyeli hakkında daha ileri çalışmalara ihtiyaç vardır.

Anahtar Kelimeler: Hayvan tipi melanom; Prognoz; Metastaz

\begin{abstract}
Objective: Animal type melanoma is a rare variant of melanoma. Our aim was to report clinical, histopathological and prognostic features in our series with 5 cases of animal type melanoma. Method: Five cases with aminal type melanoma were included in the study. As clinical parameters age, gender, location of the lesion, lymph node involvement (sentinel or regional), duration of follow-up, development of satellite/in-transit/distant metastasis, and clinical stage were evaluated. As histopathological parameters cell type, Breslow thickness, Clark level, mitotic index, presence of ulceration, regression (partial/complete), lymphohistiocytic infiltration (absent/brisk/nonbrisk), and lymphovascular/perineural invasion were evaluated.

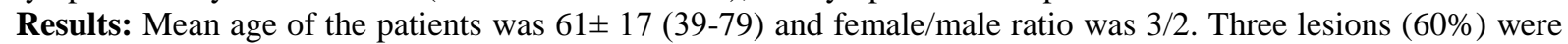
located on head and neck region and remaining two $(40 \%)$ were located on acral region. Median lesion size was $2.5 \mathrm{~cm}(1.5-4 \mathrm{~cm})$ and Breslow thickness was $7.5 \mathrm{~mm}(4-19 \mathrm{~mm})$. All lesions had Clark level V. Cell types were epitheloid in three lesions (60\%), spindle in one lesion (20\%) and epitheloid and spindle in one lesion $(20 \%)$. Ulceration, lymphovascular and perineural invasion was present in three $(60 \%)$, two lesions $(40 \%)$ and one lesion (20\%) respectively. Lymphohistiocytic infiltration was present in three lesions (60\%) (nonbrisk in two lesions, brisk in one lesion). Regression (partial) was observed in one lesion (20\%). Mitotic index was $\geq 1 \mathrm{~mm}-2$ in three lesions $(60 \%)$. Regional lymph node metastasis was present in two $(40 \%)$ cases and distant metastasis developed in two $(40 \%)$ cases.
\end{abstract}


Conclusion: In our series, animal type melanoma was observed between $4^{\text {th }}-8^{\text {th }}$ decades and both in females and males on head/neck or acral regions. In recent studies animal type melanoma has been reported to have a higher propensity to regional node metastasis but lower risk of distant metastasis compared to conventional melanoma. Similarly, lymph node involvement was high in our report, however distant metastasis rate was also high. In conclusion, further research is required about true biological potential of animal type melanoma.

Key words: Animal type melanoma; Prognosis; Metastasis

\section{Giriş}

Hayvan tipi melanom (HTM), nadir görülen bir melanom varyantıdır (1). Gri atlarda bulunan, yoğun pigment içeren melanositik tümörlere benzediği için bu isim verilmiştir (2). Bu tümörler, 15 yaş üzerindeki gri atların yaklaşık \%80'inde ortaya çıkabilmekte ve metastaz riski taşımasına rağmen çoğunlukla masum bir seyir göstermektedir $(2,3)$. İnsanlardaki benzer yoğun pigment içeren benzer melanositik tümörlere bu ismin verilmesi ilk defa Darier tarafindan 'melanosarkom' terimi ile gündeme gelmiştir (2).

HTM'ler, genel olarak histopatolojik olarak yoğun pigment içeren epiteloid ve iğsi melanositlerden oluşan bileşik veya dermal melanositik tümörlerdir. Literatürde Pigment sentezleyen melanom, belirgin pigment sentezli melanom veya pigmente epiteloid melanositom gibi farklı isimlerle de anılmaktadır (2). Epiteloid mavi nevüs ve HTM histopatolojik olarak örtüştüğü için bazı yazarlar tarafindan epiteloid mavi nevüs-HTM spektrumunda yer alan tüm tümörler pigmente epiteloid melanositom olarak adlandırılmaktadır $(2,4)$.

Tanımları kadar HTM'lerin prognozları ve konvansiyonel melanoma kıyasla seyirleri de tartışmalıdır. Bazı yayınlarda HTM'nin konvansiyonel melanoma kıyasla daha iyi bir seyre ve daha iyi prognoza sahip olduğu raporlanırken (2), bazı yayınlarda uzak metastaz ve ölüm bildirilmiş (5) ve aşikar malign sitolojik özellikler sergileyen olguların daha kötü prognoza sahip olduğu raporlanmıştır $(2,6)$. Bazı son yayınlarda HTM'de nodal metastazın konvansiyonel melanoma kıyasla daha fazla, uzak metastazın ise daha düşük olabileceğinden bahsedilmektedir $(2,7)$.

Çalışmamızda 5 olguluk HTM serimize ait klinik, histopatolojik ve prognostik özelliklerin sunulması amaçlanmıştır.

\section{Yöntem}

2000-2010 y1llar1 arasında histopatolojik tan1 alan 5 HTM olgusu çalışmaya dahil edildi. Klinik parametreler dosya ve bilgisayar kayıtlarından retrospektif olarak değerlendirildi. Klinik parametreler olarak yaş, cinsiyet, lokalizasyon, boyut, klinik evre, lenf nodu (sentinel/ bölgesel) tutulumu, takip süresi ve satellite/ intransit/ uzak metastaz gelişimi değerlendirildi. Lezyon lokalizasyonu başboyun, ekstremite, gövde ve akral bölge olarak gruplandı. Klinik evreleme için AJCC 2009 TNM evreleme sistemi kullanıld1 (8).

Histopatolojik değerlendirme için hastalara ait patolojik kesitler bir patolog ve dermatolog tarafindan tekrar incelendi. Histopatolojik olarak, hücre tipi, Clark seviyesi, Breslow kalınlığı, mitoz sayısı ve mitotik indeks, ülserasyon, regresyon, lenfohistiyositik infiltrasyon, lenfovasküler ve perinöral invazyon varlığı değerlendirildi. Regresyon parsiyel (< lezyonun \% 75'i) ve tam ( $\geq$ lezyonun \%75'i) olarak sinıflandirıldı. Lenfohistiyositik infiltrasyon; 1) Yok: Lenfohistiyositik infiltrat yok veya melanomu infiltre etmiyor; 2) Hafif: Tümörü fokal invaze eden lenfohistiyositik infiltrat var; 3) Yoğun: Tümör tabanını diffüz olarak infiltre eden ve tümör içine invazyon gösteren veya tüm invazif komponent içinde dağ 11 lım gösteren lenfohistiyositik infiltrat var, şeklinde sinıflandırıldi. Mitotik indeks; dermal komponentte $\mathrm{mm}^{2}$ başına düşen mitoz sayıs1 olarak hesapland 1 ve $<1 \mathrm{~mm}^{-2}$ and $\geq 1 \mathrm{~mm}^{-2}$ olarak siniflandirıldı.

İstatistiksel analizlerde SPSS (Statistical Package for the Social Sciences) for Windows version 15.0 programı kullanıld1. Sayısal değişkenler ortalama \pm standart sapma veya ortanca (minimum-maksimum) ile nitelik değişkenler ise sayı ve yüzde ile gösterildi.

\section{Bulgular}

Bizim çalışmamızda hastaların ortalama yaşı $61 \pm 17$ (39-79) ve kadın/erkek oranı 3/2 idi. 
Üç lezyon (\%60) baş-boyun ve kalan 2 lezyon (\%40) akral yerleşimli idi (Resim 1).

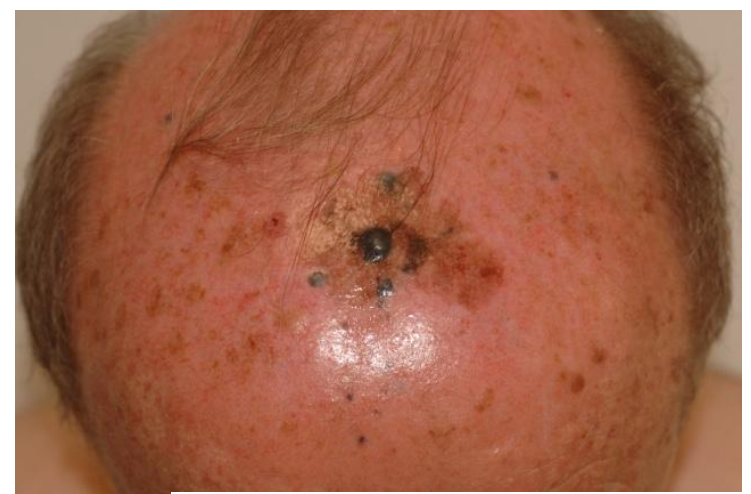

Resim 1: Skalp yerleşimli yoğun pigment içeren siyah nodül ve periferinde satellit metastazlar.

Ortanca boyut $2.5 \mathrm{~cm}(1.5-4 \mathrm{~cm})$ idi. Ortanca Breslow kalınlığ $7.5 \mathrm{~mm}(4-19 \mathrm{~mm})$ ve tüm lezyonların Clark seviyesi V idi. Üç lezyonda (\%60) hücre tipi epiteloid, bir lezyonda (\%20) iğsi ve bir lezyonda epiteloid ve iğsi karakterde idi (Resim 2).

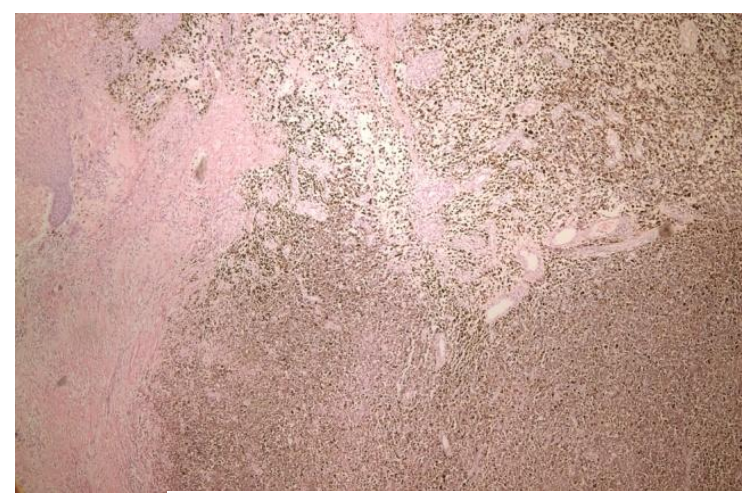

Resim 2: Hayvan tipi melanom histopatolojisinde yoğun pigment içeren epiteloid ve iğsi melanom hücreleri (HEx100).

Üç lezyonda (\%60) ülserasyon, 2 lezyonda (\%40) lenfovasküler ve bir lezyonda (\%20) perinöral invazyon mevcuttu. Lenfohistiyositik infiltrat 3 lezyonda (\%60) mevcuttu, 2 lezyonda (\%40) hafif ve bir lezyonda $(\% 20)$ yoğun idi. Bir lezyonda (\%20) parsiyel regresyon izlendi. Üç lezyonda (\%60) mitotik indeks $\geq 1$ $\mathrm{mm}^{-2}$ idi ve bu lezyonlarda mitoz sayıları sirasiyla $11 \mathrm{~mm}^{2}, 18 \mathrm{~mm}^{2}$ ve $20 \mathrm{~mm}^{2}$ idi. Bir olguda (\%20) sentinel ve 2 olguda (\%40) bölgesel lenf nodunda metastaz mevcuttu. Bir olguda (\%20) satellit ve 2 olguda (\%40) intransit metastaz izlendi.

Ortanca 2 yıllık takipte 2 olguda (\%40) uzak metastaz izlendi. Bunlardan birinde tanı anında uzak metastaz tespit edilmişti. Diğer olguda takipte 1.5 y1ll1k remisyon sonrası uzak metastaz gelişmişti. Uzak metastaz izlenen 2 olgunun biri 55 yaşında erkek diğeri 76 yaşında kadın idi. Lezyonların Breslow kalınlıkları 4 ve $19 \mathrm{~mm}$ idi. Birinde ülserasyon ve her ikisinde de lenfohistiyositik infiltrasyon (bir hafif, bir yoğun) mevcuttu. Birinde mitotik indeks $\geq 1 \mathrm{~mm}^{-2}$ idi. Lenfovasküler invazyon her ikisinde de mevcuttu, perinöral invazyon bir olguda izlenmişti. Birinde bölgesel lenf nodunda metastaz ve her iki olguda da intransit metastaz izlenmişti. Beş olguya ait klinik, histopatolojik ve prognostik özellikler Tablo 1 'de sunuldu.

\section{Tartışma}

Literatürde HTM her yaş grubunda ve her iki cinsiyette de bildirilmiştir. Sik görüldüğü yaş grubu tartışmalıdır. Bazı yayınlarda daha çok 1-2. dekadlar arasında görüldüğünden bahsedilirken, orta-ve ileri yaşlarda daha s1k görüldüğüne dair yayınlar da mevcuttur $(6,7)$. Ayrıca literatürde yer alan 66 olgunun analizinde lezyonların \%39.6's1 1-3. dekatta, $\% 31.2$ 'si 4-6. dekatta ve \%29.2'si 7 ve üzeri dekatta gösterilmiştir (7). Ayrıca HTM, erkeklerde hafif olarak daha yüksek bildirilmiştir (\%52.3 vs. \%47.7) (7). Ludgate ve ark.'nın raporladığı 22 olguluk HTM serisinde ortanca yaş 35 (5-71) ve kadın/erkek oran1 9/13 ve yakın zamanli Urso ve ark. tarafindan raporlanan 5 olguluk seride ortalama yaş 28 (4-62) ve kadın/erkek oranı $2 / 3$ olarak gösterilmiştir $(2,7)$. Bizim çalışmamızda ise hastaların ortalama yaşı $61 \pm 17$ (39-79) ve kadın/erkek oranı 3/2 idi. Çalışmamızda ortalama yaşın önceki çalışmalara göre daha yüksek görünmesi o serilerde çocuk hastaların da yer alması bizim serimizde ise HTM tanısına sahip hiçbir çocuk hastamızın olmamasına bağl1 olabilir.

Literatürde HTM, sıklıkla baş bölgesinde, ekstremitede ve gövdede bildirilmiştir (7). Ludgate ve ark.'nın serisinde 6 lezyon (\%27) baş-boyun, 6 lezyon (\%27) gövde, 7 lezyon (\%32) üst ekstremite, 2 lezyon (\%9) alt ekstremite ve bir lezyon (\%5) genital bölge yerleşimli ve Urso ve ark.'nın serisinde 3 lezyon $(\% 60)$ gövde, birer lezyon (\%20) başboyun ve ayak yerleşimli olarak raporlanmıştır 
Tablo 1: Hayvan tipi melanom olgularına ait klinik, histopatolojik ve prognostik özellikler

\begin{tabular}{|c|c|c|c|c|c|}
\hline Özellikler & Olgu 1 & Olgu 2 & Olgu 3 & Olgu 4 & Olgu 5 \\
\hline Yaş & 39 & 54 & 55 & 76 & 79 \\
\hline Cinsiyet & $\mathrm{E}$ & $\mathrm{K}$ & $\mathrm{E}$ & $\mathrm{K}$ & $\mathrm{K}$ \\
\hline Lokalizasyon & El dorsumu & Ayak parmağ1 & Skalp & Yanak & Yanak \\
\hline Boyut, cm & 2 & 2.5 & 4 & 3.7 & 1.5 \\
\hline $\begin{array}{l}\text { Breslow kalınlığ }, \\
\text { mm }\end{array}$ & 10 & 6 & 4 & 19 & 7.5 \\
\hline Clark seviyesi & $\mathrm{V}$ & $\mathrm{V}$ & $\mathrm{V}$ & $\mathrm{V}$ & $\mathrm{V}$ \\
\hline Ülserasyon & + & + & - & + & - \\
\hline $\begin{array}{l}\text { Lefovasküler } \\
\text { invazyon }\end{array}$ & - & - & + & + & - \\
\hline Perinöral invazyon & - & - & + & - & - \\
\hline $\begin{array}{l}\text { Lenfohistiyositik } \\
\text { infiltrat }\end{array}$ & Hafif & Yok & Hafif & Yoğun & Yok \\
\hline Regresyon & Yok & Yok & Yok & Parsiyel & Yok \\
\hline Mitotik indeks & $\geq 1 \mathrm{~mm}^{-2}$ & $<1 \mathrm{~mm}^{-2}$ & $<1 \mathrm{~mm}^{-2}$ & $\geq 1 \mathrm{~mm}^{-2}$ & $\geq 1 \mathrm{~mm}^{-2}$ \\
\hline Mitoz sayısı $\mathrm{mm}^{-2}$ & 11 & $<1$ & $<1$ & 20 & 18 \\
\hline $\begin{array}{l}\text { Bölgesel lenf nodu } \\
\text { metastazı }\end{array}$ & + & - & - & + & - \\
\hline Satellit metastaz & - & - & + & - & - \\
\hline İntransit metastaz & - & - & + & + & - \\
\hline $\begin{array}{c}\text { Tanı anında uzak } \\
\text { metastaz }\end{array}$ & - & - & - & + & - \\
\hline Klinik evreler & III & IIC & III & IV & IIB \\
\hline $\begin{array}{c}\text { Ortanca } 2 \text { yillık takip } \\
\text { süresinde uzak } \\
\text { metastaz }\end{array}$ & - & - & $\begin{array}{l}+ \text { (Tanıdan } 1.5 \\
\text { y1l sonra) }\end{array}$ & + & - \\
\hline
\end{tabular}

$(2,7)$. Bizim çalışmamızda ise lezyonlar başboyun (3 lezyon, \%60) ve akral (2 lezyon, \%40) yerleşimli idi.

HTM'de hücrelerin epiteloid veya iğsi olabileceği bilinmektedir (2). Bizim çalışmamizda da bununla uyumlu olarak melanom hücreleri epiteloid ve/veya iğsi karakterde izlendi. Ludgate ve ark.'nın serisinde ikişer lezyonda (\%9) ülserasyon ve regresyon izlenirken, hiçbir lezyonda lenfovasküler veya perinöral invazyon izlenmemişti (2). Bizim serimizde ise 3 lezyonda (\%60) ülserasyon, bir lezyonda (\%20) regresyon, 2 lezyonda (\%40)

lenfovasküler invazyon ve bir lezyonda (\%20) perinöral invazyon tespit edildi.

Ludgate ve ark.'nın serisinde ortanca Breslow kalınlığ $2.22 \mathrm{~mm}(0.32-11 \mathrm{~mm})$ ve lezyonların çoğunda (\%73) Clark seviyesi IV idi (2). Bizim çalışmamızda ise ortanca Breslow kalınlığı $7.5 \mathrm{~mm}(4-19 \mathrm{~mm})$ ve tüm lezyonların Clark seviyesi V idi.

Ludgate ve ark. hastaların \%47'sinde bölgesel lenf nodu metastazı tespit etmişlerdir (2). Benzer olarak Zembowicz ve ark. pigmente epiteloid melanositomları dahil ettikleri 41 olguluk serilerinde bölgesel lenf nodu metastazını \%46 olarak raporlamışlardır (4). Ve bu bulguların sonucunda yazarlar HTM'nin konvansiyonel melanoma kiyasla daha yüksek oranda bölgesel lenf nodu metastazına sahip olduğu yorumunu yapmışlardır. Fakat bunun aksine diğer bazı serilerde HTM'de bölgesel lenf nodu tutulumu düşük olarak bildirilmiştir. Orlandi ve ark. ve Scolyer ve ark. sirasiyla 7 ve 5 HTM olgusunun hiçbirinde nodal metastaz tespit etmemişlerdir $(9,10)$. Bizim serimizde ise Zembowicz ve Ludgate ve ark.'nın bulgularına 
benzer olarak 2 olguda (\%40) bölgesel lenf nodunda metastaz izlendi. Çalıșmalar arasındaki bu farklılıkların sebepleri; çalışmalardaki olgu sayılarının azlığı veya çalışmalarda HTM olarak kabul edilen lezyon tanımlarının farklılığı olabilir. Örneğin nodal metastazın düşük olduğu çalışmalarda spektrumun daha masum seyirli ucundaki epiteloid mavi nevüs benzeri HTM olgularını içeren lezyonlar çoğunlukta olabilir. Örneğin Orlandi ve ark. sadece düşük mitotik indekse sahip ve ülserasyon ve belirgin atipi içermeyen lezyonları çalışmalarına dahil etmişlerdir (9). Ludgate ve ark. ise hem malign potansiyeli aşikar (asimetrik, kötü sınırlı, yüksek atipiye sahip ve infiltratif özellikler sergileyen) lezyonları hem de biyolojik potansiyeli tam kesinleştirilememiş (iyi sınırlı, simetrik ve daha az atipi içeren) HTM olgularını dahil etmişlerdir (2). Ludgate ve ark.'nın çalışmasında pozitif lenf nodlarının çoğunluğu (\%87.5) malign potanisyeli aşikar olgularda ve yaşlılarda izlenmiştir (2). Ek olarak, biyolojik potansiyeli kesinleştirilemeyen olgular gençlerde daha yüksek oranda izlenmiştir (2). Yüksek nodal metastaz oranlarına rağmen Ludgate ve ark. sadece 2 olguda (\%9) uzak metastaz tespit etmişlerdir ve ortalama 17.6 aylık takipte, nodal metastaz tespit edilen hiç bir hastaları ölmemiştir. Ve bu bulguları sonucunda Ludgate ve ark. HTM'nin konvansiyonel melanoma kıyasla biyolojik olarak daha iyi seyirli olduğunu yorumunu yapmışlardır. Bizim serimizde ise uzak metastaz oranı $(\% 40)$ idi. Bizim çalışmamızda uzak metastaz oranının Ludgate ve ark.'nın çalışmasındakine kıyasla daha yüksek izlenmesinin sebepleri bizim serimizde tüm lezyonların malign potansiyeli aşikar lezyonlar olması ve ortanca Breslow kalınlığının onların çalıșmasındakine kıyasla daha yüksek olması olabilir. Serimizde uzak metastaz izlenen olguların biri 55 yaşında erkek diğeri 76 yaşında kadın hastaydı. Lezyonların Breslow kalınlıkları 4 ve $19 \mathrm{~mm}$ idi. Her iki olguda da lenfovasküler invazyon, birinde ülserasyon, yüksek mitoz ve perinöral invazyon mevcuttu. Her ikisinde de intransit metastaz ve birinde bölgesel lenf nodunda metastaz izlenmişti. Ludgate ve ark.'nın çalışmasında uzak metastaz izlenen 2 olgu 44 ve 53 yaşında idi (2). Breslow kalınlıkları 1.26 ve $8.5 \mathrm{~mm}$ idi. Birinde mitoz izlenmezken, birinde mitoz sayıs1 $8 \mathrm{~mm}^{-2}$ idi. Her iki olguda da ülserasyon, lenfovasküler veya perinöral invazyon izlenmemişti (2). Bizim serimizde her iki olgu da uzak metastaz gelişimini predikte edebilecek özelliklere sahipken Ludgate ve ark.'nın çalışmasında uzak metastaz izlenen 2 olguda da prediktif bir prognostik faktör izlenmemişti. Hatta Breslow kalınlığı $1.26 \mathrm{~mm}$ olan, mitotik oranı düşük olan olguları metastatik hastalık nedeniyle ölmüştü (2). Bu farklı çalışma bulguları, HTM'nin hala bilinmeyen biyolojik potansiyeleri olduğunu ve bunun netleşmesi için daha ileri çalışmalara ihtiyaç olduğunu göstermektedir. Belki de malign potansiyeli aşikar HTM ve biyolojik potansiyeli kesin olarak bilinemeyen lezyonları aynı grupta değil farklı kategorilerde değerlendirmek HTM'nin malign potansiyeli hakkında daha iyi bilgi verebilir.

\section{Sonuç}

Beş olguluk serimizde HTM 4-8. dekadlar arasında, hem kadın hem de erkeklerde, başboyun veya akral bölgede izlendi. Bölgesel lenf nodu tutulumu literatürle uyumlu olarak yüksekti. Güncel literatür bilgisinden farklı olarak serimizde uzak metastaz da yüksek oranda izlendi.

\section{Çıkar Çatışması: Yok}

\section{Referanslar}

1. Avilés-Izquierdo JA, Leis-Dosil VM, Lázaro-Ochaita P. Animal-type melanoma: clinical and dermoscopic features of 3 cases. Actas Dermosifiliogr 2014;105:186-90

2. Ludgate MW, Fullen DR, Lee J, et al. Animal-type melanoma: a clinical and histopathological study of 22 cases from a single institution. Br J Dermatol 2010;162:129-36

3. Fleury C, Berard F, Leblond A et al. The study of cutaneous melanomas in Camargue-type grayskinned horses (2): epidemiological survey. Pigment Cell Res 2000;13:47-51

4. Zembowicz A, Carney JA, Mihm MC. Pigmented epithelioid melanocytoma: a low-grade melanocytic tumor with metastatic potential indistinguishable from animal-type melanoma and epithelioid blue nevus. Am J Surg Pathol 2004;28:31-40

5. Crowson AN, Magro CM, Mihm MC Jr. Malignant melanoma with prominent pigment synthesis: 'animal type' melanoma - a clinical and histological study of six cases with a consideration of other melanocytic neoplasms with prominent pigment synthesis. Hum Pathol 1999;30:543-50 
6. Magro CM, Crowson AN, Mihm MC. Unusual variants of malignant melanoma. Mod Pathol 2006; 19:41-70

7. Urso C, Ginanneschi C, Anichini C, Paglierani, et al. Animal-type melanoma: report of five cases with sentinel node biopsy and fluorescence in-situ hybridization analysis. Melanoma Res 2014;24:47-53

8. Mangas C, Paradelo C, Puig $\mathrm{S}$, et al. Initial evaluation, diagnosis, staging, treatment, and followup of patients with primary cutaneous malignant melanoma. Consensus statement of the Network of Catalan and Balearic Melanoma Centers. Actas Dermosifiliogr 2010;101:129-42

9. Orlandi A, Costantini S, Campione E, et al. Relation between animal-type melanoma and reduced nuclear expression of glutathioneS-transferase pi. Arch Dermatol 2009;145:55-62

10. Scolyer RA, Thompson JF, Warnke K, McCarthy SW. Pigmented epithelioid melanocytoma. Am J Surg Pathol 2004;28:1114-5 